\title{
COMPARATIVE REVIEW \\ OF PRIVATE INTERNATIONAL LAW IN JAPAN
}

The year 2019 marks the $100^{\text {th }}$ anniversary of the establishment of diplomatic relations between Poland and Japan, ${ }^{1}$ and with great pleasure this memorable year also became the initial year of the conclusion of the agreement on academic cooperation between the Faculty of Law and Administration at the University of Gdańsk and the Faculty of Law, Graduate School of Law and School of Law at Kyushu University. In June 2019, an academic event "About Japanese Law" ("O prawie japońskim") was organized at the University of Gdańsk as the opportunity for lectures and staff seminar for discussing some aspects of Japanese law. This article summarizes my lecture there introducing some features of Japanese private international law with a brief comparison with Polish private international law. ${ }^{2}$

Private international law generally includes rules on international jurisdiction, choice-of-law rules, and rules on recognition and enforcement of foreign judgement. Among these, this article specifically focuses on choice-of-law rules. In the next section, as general information, the legislative history and its basic feature of Japanese and Polish private international law are contrastively explained (2. General Comparison). Then, in the latter section, specific choice-of-law provisions in Japan and Poland will be reviewed to show some comparative features (3. Some Comparative Reviews on Specific Rules).

ORCID: 0000-0002-8711-6174, DOI: 10.4467/23538724GS.20.015.12133

This work was supported by JSPS KAKENHI Grant Number 17K18542.

1 See, for example, the website of the Ministry of Foreign Affairs of Japan, "Japan-Poland Relations," https://www.mofa.go.jp/region/europe/poland/data.html (accessed: 31.12.2019).

2 This article is based on my lecture "Comparative Review of Private International Law in Japan," presented at the academic event "O prawie japońskim" held at the University of Gdańsk on 5 June 2019. I would like to express my sincere gratitude to Prof. Kamil Zeidler who kindly organized this event and to all participants for their suggestive comments during the lecture and staff seminar. 


\section{General comparison}

\section{Historical background}

This section starts with a brief introduction to the legislative history of private international law in Japan with a comparative perspective. ${ }^{3} \mathrm{It}$ is said that private international law has been unknown in Japanese society until the end of the Tokugawa feudal era. ${ }^{4}$ During the Tokugawa feudal era, private legal relationships with international elements were hardly formed due to not only the geographical condition of the island country, but also the national isolation policy (1639-1854).

The Tokugawa shogunate ended in $1867,{ }^{5}$ which resulted in beginning of the internationalization of Japanese society, or so-called "opening-up of Japan (Kaikoku)." Also, in the latter term of the Edo shogunate, with the Japan-US Treaty of Peace and Amity in 1854 for a start, Japan began to conclude treaties of international trade with other counties. However, with respect to the extraterritoriality and the tariff autonomy, the treaties concluded during that period are seen as unequal treaties.

Thus, it became a significant challenge of Meiji government to revise these treaties searching for fair trade agreements between Japan and Western countries. For such a challenge, the modernization of Japanese legal system was inevitable. For example, on 16 July 1894, Japan concluded a treaty with Britain to abolish the extraterritoriality on condition that Japanese law should be reformed in line with European systems. The codification of private international law was one of the essential part of law reform in this period. ${ }^{6}$

Binzo Kumano (1855-1899) as an official of the Ministry of Justice played a role in drafting the first code of private international law in Japan. Also, Gustave Émile Boissonade de Fontarabie (1825-1910) stayed in Japan from 1873 to 1895 as an adviser to the Ministry of Justice, presumably his guidance has been effective in the first codification process. The bill of the first code of private international law in Japan was passed as the Act No. 97 of 1890, and titled Horei, named after a Chinese term. However, in 1892,

3 For the legislative history of Japanese private international law, see, for example, J. Yokoyama, Private International Law in Japan, Kluwer Law International 2017, pp. 15 et seq.; Y. Sakurada, The Origin and Evolution of Private International Law in Japan, "Japanese Yearbook of International Law” 2013, vol. 56, pp. 164 et seq.; M. Dogauchi, Historical Development of Japanese Private International Law [in:] Japanese and European Private International Law in Comparative Perspective, eds. J. Basedow, H. Baum, Y. Nishitani, Mohr Siebrek, Tübingen 2008, pp. 27 et seq.

Y. Sakurada, The Origin and Evolution..., supra note 3, p. 164.

5 In 1867, Yoshinobu Tokugawa (the $15^{\text {th }}$ shogun of Tokugawa) has returned political power to the Emperor. This historical event is called "Taisei Hokan" and known as a landmark showing the end of Tokugawa shogunate.

${ }^{6}$ For the law reform in this period, it was also essential to codify the Civil Code and the Code of Civil Procedure. 
it is decided to postpone the implementation of Horei, together with that of the Civil Code and the Commercial Code, by the Act No. 8 of 1892, until the end of 1896. At that time, the government intended to draft a new Civil Code and new statutes of private international law, which resulted in the fact that the first Horei was never put into force.

In 1896, the Cabinet established the Legal Research Council [Hoten-chosa-kai], of which the chairperson was Hirofumi Ito (1841-1909), the prime minister at that time. Nobushige Hozumi (1855-1926) and Saburo Yamada (1869-1965) conducted a comparative law survey, before proceeding to the drafting of the second Horei.

The bill of the second Horei and the bill of the Civil Code were submitted to the parliament in December 1897. Finally, the second Horei, as the Act No. 10 of 1898, was passed into law on 21 June 1898, and came into force on 16 July 1898.

The second Horei experienced a significant amendment in 1989 (Act No. 27 of 1989). ${ }^{7}$ Before the amendment, for matters relating to marriage or the parent-child relationship, there were connecting factors such as the "husband's" or "father's" nationality. However, the Act No. 27 of 1989 abolished these connecting factors by paying more attention to the importance of gender equality.

In the $21^{\text {st }}$ century, with a comparative study on recent legislative efforts in private laws, the government decided to renew its code of private international law. In 2006, the Act on General Rules for Application of Laws (hereinafter "2006 Japanese PIL Act”) was enacted. ${ }^{8}$ This act entered into force on 1 January 2007, replacing the old PIL statute of $1898 .{ }^{9}$

In Poland, private international law has been developed from a different background. The legislative history on private international law in Poland dates back to the mid-1920s. Similar to Japan, Poland has codified its private international law as

7 For the English translation of the Horei of 1898 made by Masato Dogauchi, Yoshiaki Nomura, Jun Yokoyama, see: J. Torii, Revision of Private International Law in Japan, "The Japanese Annual of International Law" 1990, no. 33, pp. 67 et seq.; The Study Group of the New Legislation of Private International Law, Draft Articles on the Law Applicable to Contractual and Non-Contractual Obligation (1), "The Japanese Annual of International Law" 1996, no. 39, pp. 186 et seq.; K. Anderson, Y. Okuda, Horei, Act on the Application of Laws: Law No. 10 of 1898, "Asian-Pacific Law and Policy Journal" 2002, vol. 3, no. 1, pp. 230 et seq.

8 For the English translation of the 2006 Japanese PIL Act, see: Kent Anderson, Yasuhiro Okuda, Translation of Japan's Private International Law: Act on the General Rules of Application of Laws [Ho no Tekiyo ni Kansuru Tsusokubo]: Law No. 10 of 1898 (as newly titled and amended 21 June 2006)," "Asian-Pacific Law and Policy Journal" 2006, vol. 8, no. 1, pp. 138 et seq. Also, for the overview of this Act of 2006, see, for example, N. Iguchi, N. Kamimura, Japan [in:] Asian Conflict of Laws: East and South East Asia, ed. A.C. Leyda, Kluwer Law International 2015, pp. 67 et seq.; Appendix: Act on General Rules for Application of Laws, "The Japanese Annual of International Law" 2007, no. 50 , pp. 87 et seq.

9 H. Wanami, Background and Outline of the Modernization of Japanese Private International Law [in:] Japanese and European Private International Law in Comparative Perspective, eds. J. Basedow, H. Baum, Y. Nishitani, Mohr Siebrek, Tübingen 2008, pp. 61 et seq. 
an independent set of code. The first PIL statute in Poland was enacted on 2 August 1926. ${ }^{10}$ Afterwards, under the initiative of Professor Kazimierz Przybyłowski, the effort to further develop principles of private international law in Poland resulted in the Act of 12 November 1965 on Private International Law, which was enacted in replacement of the previous statute of $1926 .{ }^{11}$

In the $21^{\text {st }}$ century, Poland joined the European Union in 2004, and its national laws, including private international law, were also affected by this historical event. Firstly, as Poland became a member state of the EU, its national laws are applied to matters which are not regulated by EU legislation. ${ }^{12}$ Secondly, some principles in its national legislations needed to be adjusted in line with the harmonized legislative effort in the EU, and private international law was no exception. ${ }^{13}$ As a result, Act of 4 February 2011 on Private International Law (hereinafter "2011 Polish PIL Act") was enacted. ${ }^{14}$

For the purpose of highlighting a few features of Japanese law, the following sections will compare some aspects of Polish and Japanese choice-of-law rules.

\section{General comparison between Polish and Japanese private international law}

If we overview the Polish and Japanese statute on private international law, in either country, most of the choice-of-law rules are designed to be bilateral. In other words, foreign laws are applicable on equal terms with the forum law.

Speaking of this similarity in their bilateral structure of choice-of-law code in principle, Poland and Japan also show similar exceptions on this point, as shown in table 1. For example, if the issue of incapacitation is decided in the Polish court, "Polish law shall apply" (Article 13 of the 2011 Polish PIL Act). Similarly, if the Japanese court makes a ruling for commencement of guardianship, curatorship or assistance, such ruling shall be made "under Japanese law" (Article 6 of the 2006 Japanese PIL Act).

10 M. Pazdan, Das neue polnische Gesetz, über das international Privatrecht, "Privat- und Verfahrensrechts [IPRax]" 2012, Heft 1, p. 77.

11 Ibidem, p. 77. In Japan, the Polish Act of 1965 is introduced by H. Matsuoka, New Polish Private International Law [Shin Poland kokusai-shibo], "Osaka Law Review” [Handai Hogaku], 1967, vol. 61, pp. 39 et seq.; T. Kawakami, New Private International Law in Poland [Poland shin kokusai-shibo], "Journal of the Japanese Institute of International Business Law" [Kaigai Shoji Homu] 1966, vol. 54, pp. 24 et seq. See also: Y. Tameike, Draft Act of 1961 on Private International Law in Poland [1961-nen Poland kokusai-shibo soan], "Kyoto Law Review” [Hogaku Ronso] 1963, pp. 73 et seq.

12 A. Frąckowiak-Adamska, A. Guzewicz, Ł. Petelski, Poland [in:] Cross-Border Litigation in Europe, eds. P. Beaumont, M. Danov, K. Trimmings, B. Yüksel, Hart Publishing 2017, p. 221.

13 A. Mączyński, Polish Private International Law "Yearbook of Private International Law" 2004, vol. 6, pp. 203 et seq.

14 Journal of Laws 2011, No. 80, item 432. English translation is available at: http://pil.mateuszpilich.edh.pl/New_Polish_PIL.pdf (accessed: 31.12.2019). In Japan, the 2011 Polish PIL Act is introduced by T. Kasahara, The Revision of Polish Private International Law [Poland Kokusaishibo No Kaisei Ni Tsuite], “Toyo Law Review” [Toyo Hogaku] 2012, 56(1), pp. 203 et seq. 
In the issue on declaration of death, a similar comparison can be made between Article 14 of the 2011 Polish PIL Act and Article 6 of the 2006 Japanese PIL Act.

Table 1. Incapacitation etc. and Adjudication of Disappearance under Japanese and Polish PIL Act

\begin{tabular}{|c|c|}
\hline 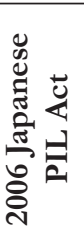 & $\begin{array}{l}\text { Article } 5 \\
\text { The court may make a ruling for commencement of guardianship, curatorship or assis- } \\
\text { tance (hereinafter collectively referred to as a "Ruling for Commencement of Guard- } \\
\text { ianship, etc.") under Japanese law where a person who is to become an adult ward, } \\
\text { person under curatorship or person under assistance has domicile or residence in Japan } \\
\text { or has Japanese nationality. }\end{array}$ \\
\hline 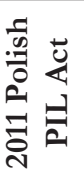 & $\begin{array}{l}\text { Article } 13 \\
\text { 1. Incapacitation is governed by the law of nationality of the person concerned. } \\
\text { 2. If the Polish court decides on the incapacitation of a foreigner, Polish law shall apply. }\end{array}$ \\
\hline 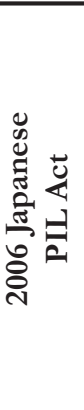 & $\begin{array}{l}\text { Article } 6 \\
\text { (1) The court may make an adjudication of his/her disappearance under Japanese law } \\
\text { where an absentee had domicile in Japan or had Japanese nationality, at the latest point } \\
\text { of time when he/she was found to be alive. } \\
\text { (2) Even in the case where the preceding paragraph does not apply, if an absentee's } \\
\text { property is situated in Japan, or if an absentee's legal relationship should be governed } \\
\text { by Japanese law or is connected with Japan in the light of the nature of the legal re- } \\
\text { lationship, the domicile or nationality of the party and any other circumstances con- } \\
\text { cerned, the court may, by applying Japanese law, make an adjudication of the absentee's } \\
\text { disappearance only with regard to said property or said legal relationship, respectively. }\end{array}$ \\
\hline 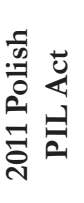 & $\begin{array}{l}\text { Article } 14 \\
\text { 1. Declaration of death of a person lost shall be subject to his or her national law. The } \\
\text { same rules shall apply to the determination of the death or of the time of one's death. } \\
\text { 2. Where Polish court decides on the declaration of death, or on the determination of } \\
\text { the death (of the time of death) of a foreigner, then Polish law shall apply. }\end{array}$ \\
\hline
\end{tabular}

In addition to the common basis of bilateral structure of choice-of-law rules, both the 2011 Polish PIL Act and the 2006 Japanese PIL Act follow the principle to apply "the most closely connected law." For the adoption of this principle, it goes without saying that the contribution by Friedrich Carl von Savigny (1779-1861) has been so influential. Savigny focused on "legal relationships" and sought to identify the state in which each relationship had its "seat." Legal questions in the field of private law are divided into categories of legal relationships, and in each category, its seat is identified through "connecting factor." 'This approach established by Savigny is still considered as the traditional basic approach to design choice-of-law rules not only in Europe, but also in the rest of the world. ${ }^{15}$

15 See, for example, S.C. Symeonides, Choice of Law, Oxford University Press, Oxford 2016, pp. $50,51$. 
In both jurisdictions this principle functions as a way to implement specific choice-of-laws being a general fall-back rule. For example, in Poland this role can be observed in Article 8 (2), Article 9 (2), Article 10 (1), and Article 51 (2) in the 2011 Polish PIL Act. In Japan, the similar role of this principle can be observed, for example, in Article 8, Article 25, Article 38, and Article 40. Besides, the principle to apply the most closely connected law also works to provide exceptional choiceof-law rules. ${ }^{16}$

\section{Some comparative reviews on specific rules}

\section{Nationality}

As a general tendency, while most common law countries adopt "domicile" as the traditional personal connecting factor, most civil law countries traditionally adopt "nationality" as the basic connecting factor in relation to legal capacity and family law issues. ${ }^{17}$ Poland and Japan commonly show the legislative attitude to take "nationality" as the fundamental connecting factor in issues of legal capacity and family law, as listed in table 2 .

Table 2. "Nationality" as a connecting factor in issues of legal capacity and family law under Japanese and Polish PIL Act

\begin{tabular}{|l|l|}
\hline & $\begin{array}{l}\text { Article 4. (1) The legal capacity of a person to act shall be governed by his/her national } \\
\text { law. } \\
\text { (2) Notwithstanding the preceding paragraph, when a person who has performed a ju- } \\
\text { ridical act is subject to the limitation of his/her capacity to act under his/her national } \\
\text { law but has full capacity to act under the law of the place where the act is done (lex loci } \\
\text { actus), that person shall be deemed to have full capacity to act, only in cases where all } \\
\text { the parties were present in a place governed by the same law at the time of the juridical } \\
\text { act. } \\
\text { (3) The preceding paragraph shall not apply to a juridical act to be governed by the } \\
\text { provisions of family law or inheritance law, or a juridical act relating to real property } \\
\text { situated in a place governed by a different law from the law of the place where the act } \\
\text { was done. }\end{array}$ \\
\hline
\end{tabular}

16 In the 2011 Polish PIL Act, see, for example, Article 32 and Article 43. In the 2006 Japanese PIL Act, see, for example, Article 12.

17 See, for example, J. Hill, Domicile, nationality and habitual residence [in:] Clarkson and Hill's Conflict of Laws, eds. J. Hill, M. Ní Shúilleabháin, $5^{\text {th }}$ edition, Oxford University Press, Oxford 2016, pp. 315 et seq. 


\begin{tabular}{|c|c|}
\hline 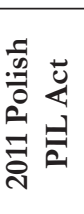 & 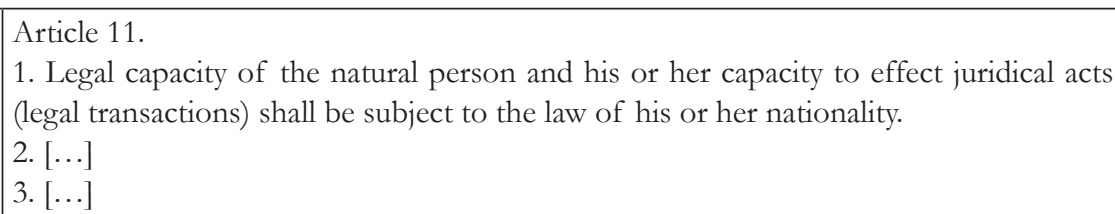 \\
\hline 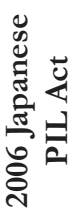 & - \\
\hline 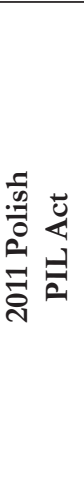 & 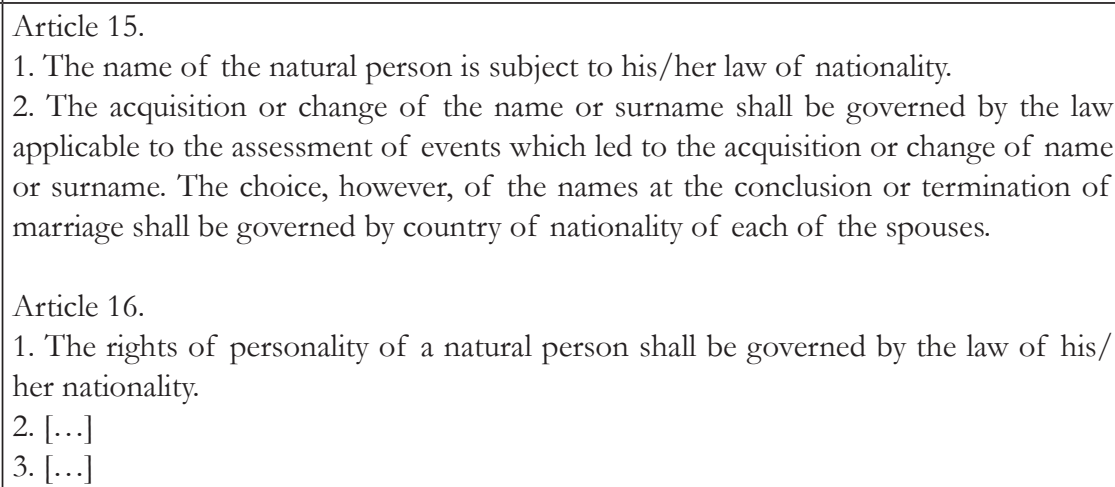 \\
\hline 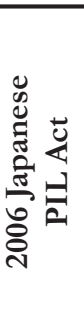 & $\begin{array}{l}\text { Article 24. (1) The formation of a marriage shall be governed by the national law of } \\
\text { each party. } \\
\text { (2) The formalities for a marriage shall be governed by the law of the place where the } \\
\text { marriage is celebrated (lex loci celebrationis). } \\
\text { (3) Notwithstanding the preceding paragraph, the formalities that comply with the na- } \\
\text { tional law of either party to a marriage shall be valid; provided, however, that this shall } \\
\text { not apply where a marriage is celebrated in Japan and either party to the marriage is } \\
\text { a Japanese national. }\end{array}$ \\
\hline 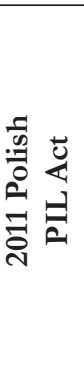 & $\begin{array}{l}\text { Article } 48 . \\
\text { The ability to conclude marriage shall be determined for each of the parties by the law } \\
\text { of his or her nationality at the time of concluding the marriage. } \\
\text { Article } 49 \text {. } \\
\text { 1. The form or the marriage is subject to the law of the country in which it is celebrated. } \\
\text { 2. Where the marriage is celebrated outside the territory of the Republic of Poland, it } \\
\text { shall be sufficient to comply with the form required by laws of the nationality, of the } \\
\text { permanent or habitual residence of both spouses. }\end{array}$ \\
\hline 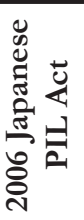 & $\begin{array}{l}\text { Article } 25 \text {. The effect of a marriage shall be governed by the national law of the hus- } \\
\text { band and wife if their national law is the same, or where that is not the case, by the law } \\
\text { of the habitual residence of the husband and wife if their law of the habitual residence } \\
\text { is the same, or where neither of these is the case, by the law of the place most closely } \\
\text { connected with the husband and wife. }\end{array}$ \\
\hline
\end{tabular}




\begin{tabular}{|c|c|}
\hline 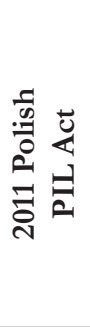 & $\begin{array}{l}\text { Article } 51 . \\
\text { 1. Personal and property relationships between spouses shall be subject to the law of } \\
\text { their current common nationality. } \\
\text { 2. In the absence of the common nationality, the law of the country in which both } \\
\text { spouses have their place of permanent residence - or, in the absence of the latter, of } \\
\text { their common habitual residence - shall apply. Where the spouses are not habitually } \\
\text { resident in the same country, the law of the country with which both are otherwise } \\
\text { most strictly connected shall apply. }\end{array}$ \\
\hline 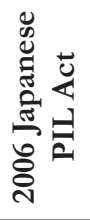 & $\begin{array}{l}\text { Article } 27 . \text { Article } 25 \text { shall apply mutatis mutandis to divorce; provided, however, that if } \\
\text { either husband or wife is a Japanese national who has habitual residence in Japan, their } \\
\text { divorce shall be governed by Japanese law. }\end{array}$ \\
\hline 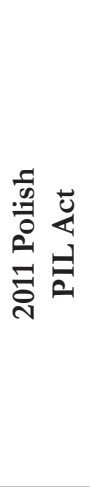 & $\begin{array}{l}\text { Article } 54 . \\
\text { 1. Dissolution of marriage shall be governed by the common law of the nationality of } \\
\text { spouses at the time of the dissolution request. } \\
\text { 2. In the absence of the common nationality, the law of the country in which both } \\
\text { spouses at the time of requesting the dissolution of the marriage have their place of } \\
\text { permanent residence - or, in the absence of the latter at that moment, of their last } \\
\text { common habitual residence, provided that at least one of them is still habitually resi- } \\
\text { dent in that latter country - shall apply. } \\
\text { 3. Where the requirements of paragraphs (1) and (2) are not met, the dissolution of } \\
\text { marriage shall be governed by Polish law. } \\
\text { 4. Provisions of paragraphs (1) to (3) apply mutatis mutandis to the legal separation } \\
\text { of spouses. }\end{array}$ \\
\hline 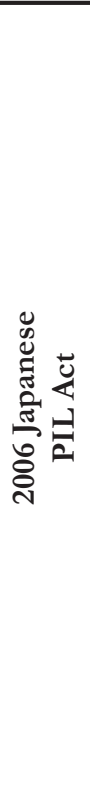 & $\begin{array}{l}\text { Article 28. (1) If a child shall be treated as a child born in wedlock under the national } \\
\text { law of either the husband or wife at the time of the child's birth, the child shall be } \\
\text { deemed to be a child born in wedlock. } \\
\text { (2) If a husband has died before his child's birth, the husband's national law at the time } \\
\text { of his death shall be deemed to be the husband's national law set forth in the preceding } \\
\text { paragraph. } \\
\text { Article 29. (1) In case of a child born out of wedlock, the formation of a parent-child } \\
\text { relationship with regard to the father and the child shall be governed by the father's } \\
\text { national law at the time of the child's birth, and with regard to the mother and } \\
\text { the child by the mother's national law at said time. In this case, when establishing } \\
\text { a parent-child relationship by acknowledgment of parentage of a child, if obtaining } \\
\text { the acceptance or consent from the child or a third party is required for acknowl- } \\
\text { edgement under the child's national law at the time of the acknowledgement, such } \\
\text { requirement shall also be satisfied. } \\
\text { (2) Acknowledgement of parentage of a child shall be governed by the law designated } \\
\text { in the first sentence of the preceding paragraph, or by the national law of the acknowl- } \\
\text { edging person or of the child at the time of the acknowledgement. In this case, if the } \\
\text { acknowledging person's national law is to govern, the second sentence of the preceding } \\
\text { paragraph shall apply mutatis mutandis. }\end{array}$ \\
\hline
\end{tabular}




\begin{tabular}{|c|c|}
\hline & $\begin{array}{l}\text { (3) If a father has died before his child's birth, the father's national law at the time of } \\
\text { his death shall be deemed to be the father's national law set forth in paragraph (1). If } \\
\text { the person referred to in the preceding paragraph has died before the acknowledgment, } \\
\text { the person's national law at the time of his/her death shall be deemed to be the person's } \\
\text { national law set forth in said paragraph. } \\
\text { Article 30. (1) A child shall acquire the status of a child born in wedlock if the child is } \\
\text { legitimated under the national law of the father or the mother or of the child at the time } \\
\text { when the facts constituting the requirements for legitimation are completed. } \\
\text { (2) If a person referred to in the preceding paragraph has died before the facts constituting } \\
\text { the requirements for legitimation are completed, the person's national law at the time of } \\
\text { his/her death shall be deemed to be the person's national law set forth in said paragraph. }\end{array}$ \\
\hline 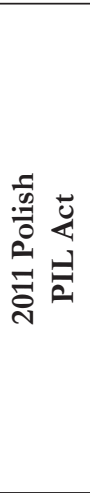 & $\begin{array}{l}\text { Article } 55 . \\
\text { 1. Determination and negation of the child's origin shall be subject to the law of na- } \\
\text { tionality of the child at the moment of his birth. } \\
\text { 2. If the law of the nationality of the child at the moment of his birth does not provide } \\
\text { for the affiliation of the child to a putative father, it shall be governed by the law of the } \\
\text { nationality of the child at the moment of the affiliation. } \\
\text { 3. The recognition of the child shall be subject to the law of the nationality of the } \\
\text { child at the time of the recognition. Should this law not provide for the recognition of } \\
\text { the child, the law of the nationality of the child at the moment of his birth shall apply, } \\
\text { where the latter provides for the recognition. } \\
\text { 4. Recognition of child conceived but unborn shall be subject to the law of the country } \\
\text { of his mother's nationality at the time of recognition. }\end{array}$ \\
\hline 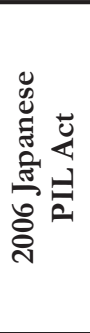 & $\begin{array}{l}\text { Article 31. (1) Adoption shall be governed by the national law of an adoptive parent at } \\
\text { the time of the adoption. In this case, if obtaining the acceptance or consent from the } \\
\text { person to be adopted or a third party, or obtaining permission or any other decision } \\
\text { from a public authority is required for adoption under the national law of the person to } \\
\text { be adopted, such requirement shall also be satisfied. } \\
\text { (2) The termination of a family relationship between an adopted child and his/her } \\
\text { natural relatives by blood and dissolution of adoption shall be governed by the law } \\
\text { applicable under the first sentence of the preceding paragraph. }\end{array}$ \\
\hline 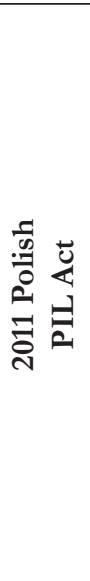 & $\begin{array}{l}\text { Article } 57 . \\
\text { 1. Adoption shall be subject to the law of the country whose the adopter is a national. } \\
\text { 2. The common adoption by the spouses shall be subject to their common law of } \\
\text { nationality. In the absence of the common nationality, the law of the country in which } \\
\text { both spouses have their place of permanent residence - or, in the absence of the latter, } \\
\text { of their common habitual residence - shall apply. Where the spouses are not habitually } \\
\text { resident in the same country, the law of the country with which both are otherwise } \\
\text { most strictly connected shall apply. } \\
\text { Article } 58 \text {. } \\
\text { The adoption cannot take place without observing the rules of the law of the person } \\
\text { who is to be adopted, concerning his and his legal representative's consent to the adop- } \\
\text { tion, and the permission of the competent State authority, as well as these concerning } \\
\text { the adoption restrictions because of the change of the place of previous the permanent } \\
\text { residence to the place of residence in the other country. }\end{array}$ \\
\hline
\end{tabular}




\begin{tabular}{|l|l|}
\hline & $\begin{array}{l}\text { Article 33. Family relationships or rights and obligations arising therefrom other than } \\
\text { those provided for in Article 24 to Article } 32 \text { shall be governed by the national law of } \\
\text { the party concerned. } \\
\text { Article 35. (1) Guardianship, curatorship or assistance (hereinafter collectively referred } \\
\text { to as "Guardianship, etc.") shall be governed by the national law of a ward, person } \\
\text { under curatorship or person under assistance (collectively referred to as a "Ward, etc." } \\
\text { in paragraph (2)). } \\
\text { (2) Notwithstanding the preceding paragraph, in the following cases where a foreign } \\
\text { national is a Ward, etc., a ruling of appointment of a guardian, curator or assistant and } \\
\text { other ruling concerning Guardianship, etc. shall be governed by Japanese law: } \\
\text { (i) where the grounds for commencement of Guardianship, etc. of the foreign national } \\
\text { exist under his/her national law, and there is no person to conduct the affairs of Guard- } \\
\text { ianship, etc. in Japan; or } \\
\text { (ii) [...] }\end{array}$ \\
\hline - &
\end{tabular}

It is also notable that "party autonomy" is treated as an exception to the rule of nationality in either jurisdiction. However, the ways of adopting party autonomy in international family law seem to provide a significant comparison between Polish and Japanese law (see: table 3 and table 4).

On the one hand, Article 52 of 2011 Polish Act shows a similarity with Article 26 of 2006 Japanese PIL Act (see: table 3). Both of these provisions suggest that, the idea of party autonomy is introduced in the issue of marital property regime or marriage agreement in either jurisdiction.

On the other hand, the choice-of-law rules on succession issues highlight the different legislative developments of private international law in Japan and Poland (see: table 4). According to Article 66a of Polish PIL Act, the choice-of-law issues on succession matters shall be determined by the "Regulation (EU) No. 650/2012 of the European Parliament and of the Council of 4 July 2012 on jurisdiction, applicable law, recognition and enforcement of decisions and acceptance and enforcement of authentic instruments in matters of succession and on the creation of a European Certificate of Succession." ${ }^{18}$ In the Regulation, a general rule to apply "the law of the State in which the deceased had his habitual residence at

18 The text of the Regulation (EU) No. 650/2012 of the European Parliament and of the Council of 4 July 2012 can be downloaded from the EUR-Lex website, available at: https:// eur-lex.europa.eu/legal-content/EN/TXT/?qid=1588045243353\&uri=CELEX:32012R0650 (accessed: 28.04.2020). 
the time of death" is adopted (Article 21 of the Regulation (EU) No. 650/2012). However, there is a limited party autonomy which allows a person to choose "the law of the State whose nationality he possesses at the time of making the choice or at the time of death" as an applicable law on succession (Article 22 of the Regulation (EU) No. 650/2012). Also, extensive choice-of-law rules in the Regulation including Article 24 (Dispositions of property upon death other than agreements as to succession) and Article 25 (Agreements as to succession) are noteworthy as these provisions that are not found in Japanese PIL Act.

Comparatively, Japanese private international law still stands on traditional rules to apply the national law of the decedent/testator (Article 36 and 37 of 2006 Japanese PIL Act). ${ }^{19}$ In relation with this issue, it should be noted that Japan has ratified the "Convention of 5 October 1961 on the Conflicts of Laws Relating to the Form of Testamentary Dispositions" in 1964 with the enactment of the Act No. 100 of $1964 .{ }^{20}$

Table 3. "Party autonomy" in international family law under Japanese and Polish PIL Act

\begin{tabular}{|l|l|}
\hline & $\begin{array}{l}\text { Article 26. (1) The preceding Article shall apply mutatis mutandis to the marital prop- } \\
\text { erty regime. } \\
\text { (2) Notwithstanding the preceding paragraph, if a husband and wife have designated } \\
\text { one of the laws listed in the following as the governing law by means of a document } \\
\text { signed by them and dated, their marital property regime shall be governed by the law } \\
\text { thus designated. In this case, the designation shall be effective only for the future: } \\
\text { (i) the law of the country where either husband or wife has nationality; } \\
\text { (ii) the law of the habitual residence of either husband or wife; or } \\
\text { (iii) with regard to marital property regime regarding real property, the law of the place } \\
\text { where the real property is situated. } \\
\text { (3) The marital property regime to which a foreign law should be applied pursuant to } \\
\text { the preceding two paragraphs may not be asserted against a third party without knowl- } \\
\text { edge, to the extent that it is related to any juridical act done in Japan or any property } \\
\text { situated in Japan. In this case, in relation to such third party, the marital property regime } \\
\text { shall be governed by Japanese law. } \\
\text { (4) Notwithstanding the preceding paragraph, a contract on marital property concluded } \\
\text { under a foreign law pursuant to paragraph (1) or (2) of this Article may be asserted } \\
\text { against a third party when it is registered in Japan. }\end{array}$ \\
\hline
\end{tabular}

19 See, for example, S. Nakano, Party Autonomy in International Family and Succession Law [Kokusai-shinzoku, Sozoku-ho Ni Okeru Tojishajichi No Gensoku], "Kobe Law Journal” [Kobe Hogaku Zasshi], 2015, vol. 65, no. 2, pp. 1 et seq.

20 As to the Hague Convention of 5 October 1961, full text and status table are available at: https://www.hcch.net/en/instruments/conventions/full-text/?cid=40 (accessed: 28.04.2020). 


\begin{tabular}{|l|l|}
\hline & $\begin{array}{l}\text { Article } 52 . \\
\text { 1. The spouses may make their property relationships governed by the law of nationali- } \\
\text { ty of the either spouse or by the law of the country in which one of them is permanent } \\
\text { or habitually resident. The choice of law may be made also before the conclusion of } \\
\text { marriage. } \\
\text { 2. The marriage agreement shall be subject to the law chosen by the parties according } \\
\text { to the paragraph (1). In the absence of the law choice, the marriage agreement shall be } \\
\text { governed by the law applicable to the personal and property relationships between the } \\
\text { spouses at the time of entering into the agreement. } \\
\text { 3. When choosing the law applicable to property relationships between spouses or } \\
\text { for the marriage agreement, it shall be sufficient to comply with the form prescribed } \\
\text { for marriage agreements either by the law chosen or by the law of the country in } \\
\text { which the law choice was made. }\end{array}$ \\
\hline
\end{tabular}

Table 4. Choice-of-law rules on succession under Japanese PIL Act and Regulation (EU) No.650/2012 of the European Parliament and of the Council

\begin{tabular}{|l|l|}
\hline & - \\
\hline & $\begin{array}{l}\text { Article 20. (Universal application) } \\
\text { Any law specified by this Regulation shall be applied whether or not it is the law of }\end{array}$ \\
\hline a Member State.
\end{tabular}




\begin{tabular}{|c|c|}
\hline 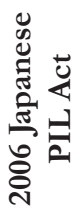 & - \\
\hline 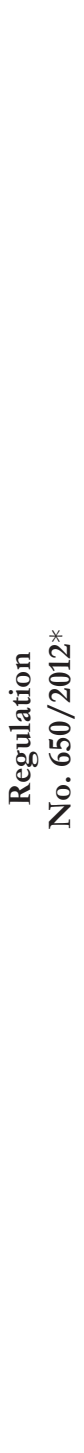 & 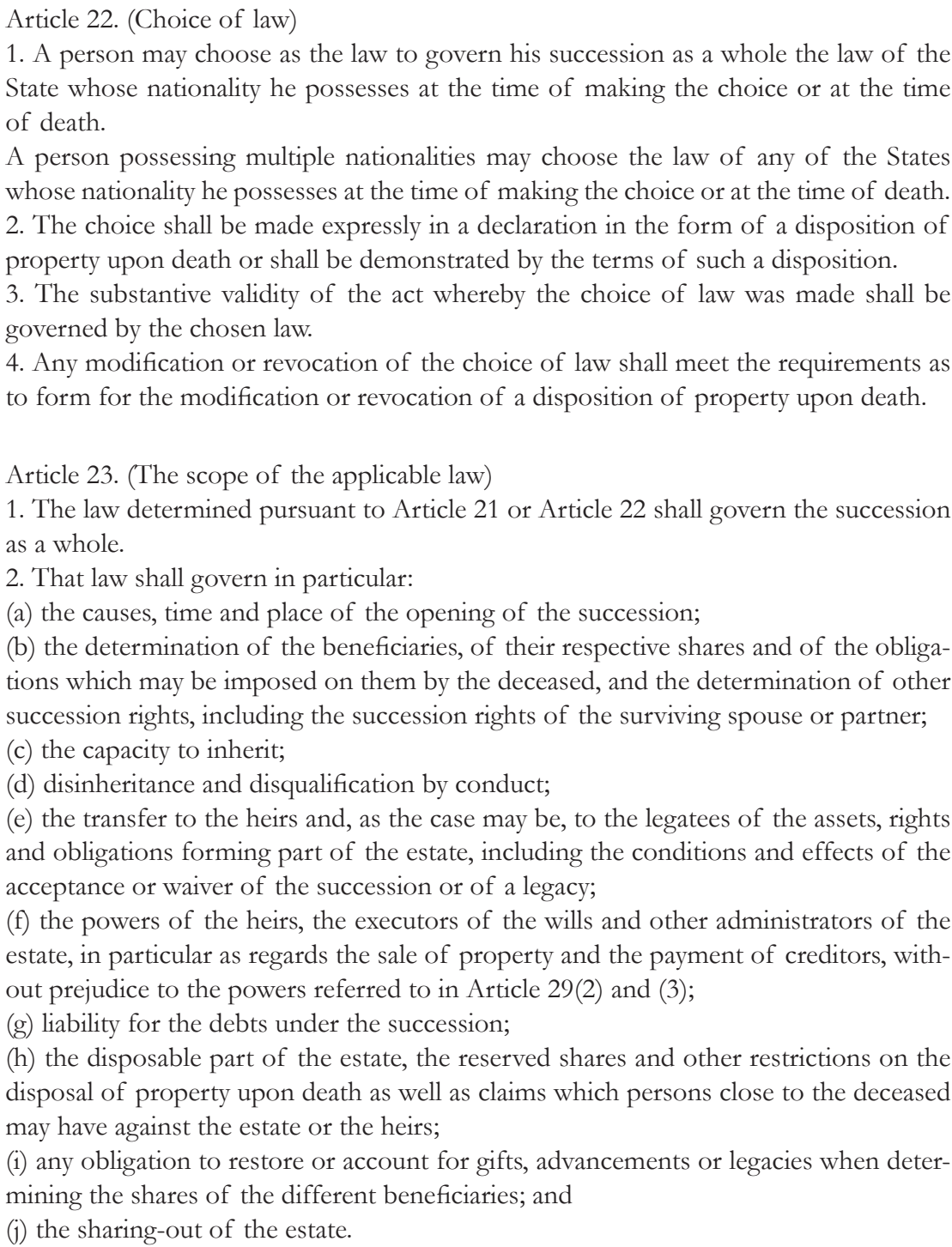 \\
\hline
\end{tabular}




\begin{tabular}{|c|c|}
\hline 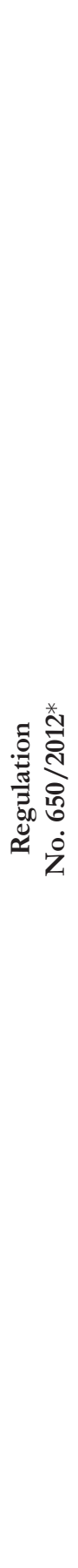 & $\begin{array}{l}\text { Article } 25 \text {. (Agreements as to succession) } \\
\text { 1. An agreement as to succession regarding the succession of one person shall be gov- } \\
\text { erned, as regards its admissibility, its substantive validity and its binding effects between } \\
\text { the parties, including the conditions for its dissolution, by the law which, under this } \\
\text { Regulation, would have been applicable to the succession of that person if he had died } \\
\text { on the day on which the agreement was concluded. } \\
\text { 2. An agreement as to succession regarding the succession of several persons shall be } \\
\text { admissible only if it is admissible under all the laws which, under this Regulation, would } \\
\text { have governed the succession of all the persons involved if they had died on the day on } \\
\text { which the agreement was concluded. } \\
\text { An agreement as to succession which is admissible pursuant to the first subparagraph } \\
\text { shall be governed, as regards its substantive validity and its binding effects between } \\
\text { the parties, including the conditions for its dissolution, by the law, from among those } \\
\text { referred to in the first subparagraph, with which it has the closest connection. } \\
\text { 3. Notwithstanding paragraphs } 1 \text { and } 2 \text {, the parties may choose as the law to govern } \\
\text { their agreement as to succession, as regards its admissibility, its substantive validity and } \\
\text { its binding effects between the parties, including the conditions for its dissolution, the } \\
\text { law which the person or one of the persons whose estate is involved could have chosen } \\
\text { in accordance with Article } 22 \text { on the conditions set out therein. } \\
\text { Article } 26 . \text { (Substantive validity of dispositions of property upon death) } \\
\text { 1. For the purposes of Articles } 24 \text { and } 25 \text { the following elements shall pertain to sub- } \\
\text { stantive validity: } \\
\text { (a) the capacity of the person making the disposition of property upon death to make } \\
\text { such a disposition; } \\
\text { (b) the particular causes which bar the person making the disposition from disposing } \\
\text { in favour of certain persons or which bar a person from receiving succession property } \\
\text { from the person making the disposition; } \\
\text { (c) the admissibility of representation for the purposes of making a disposition of } \\
\text { property upon death; }\end{array}$ \\
\hline
\end{tabular}




\begin{tabular}{|c|c|}
\hline 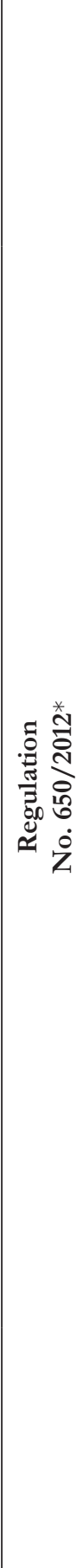 & 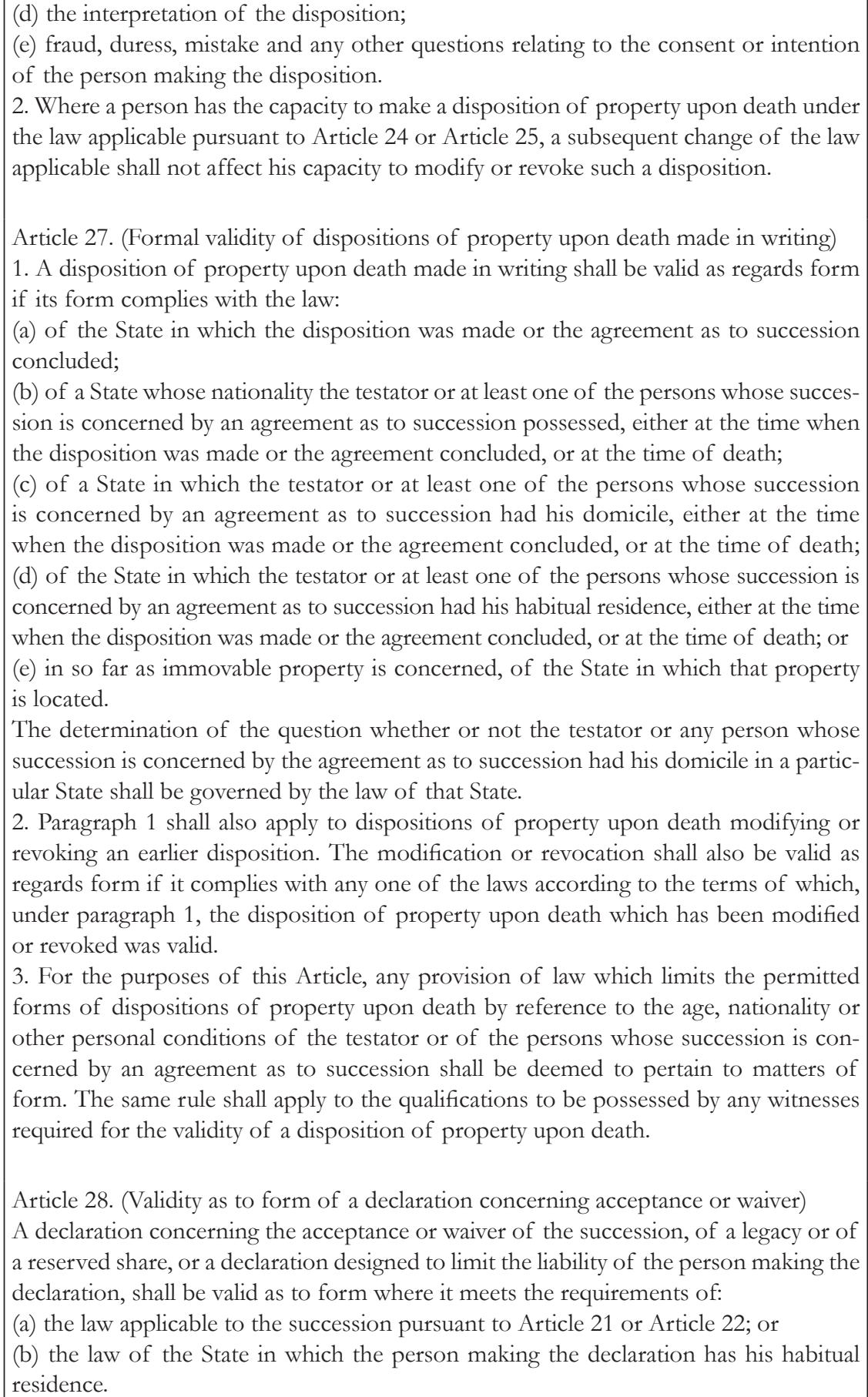 \\
\hline
\end{tabular}




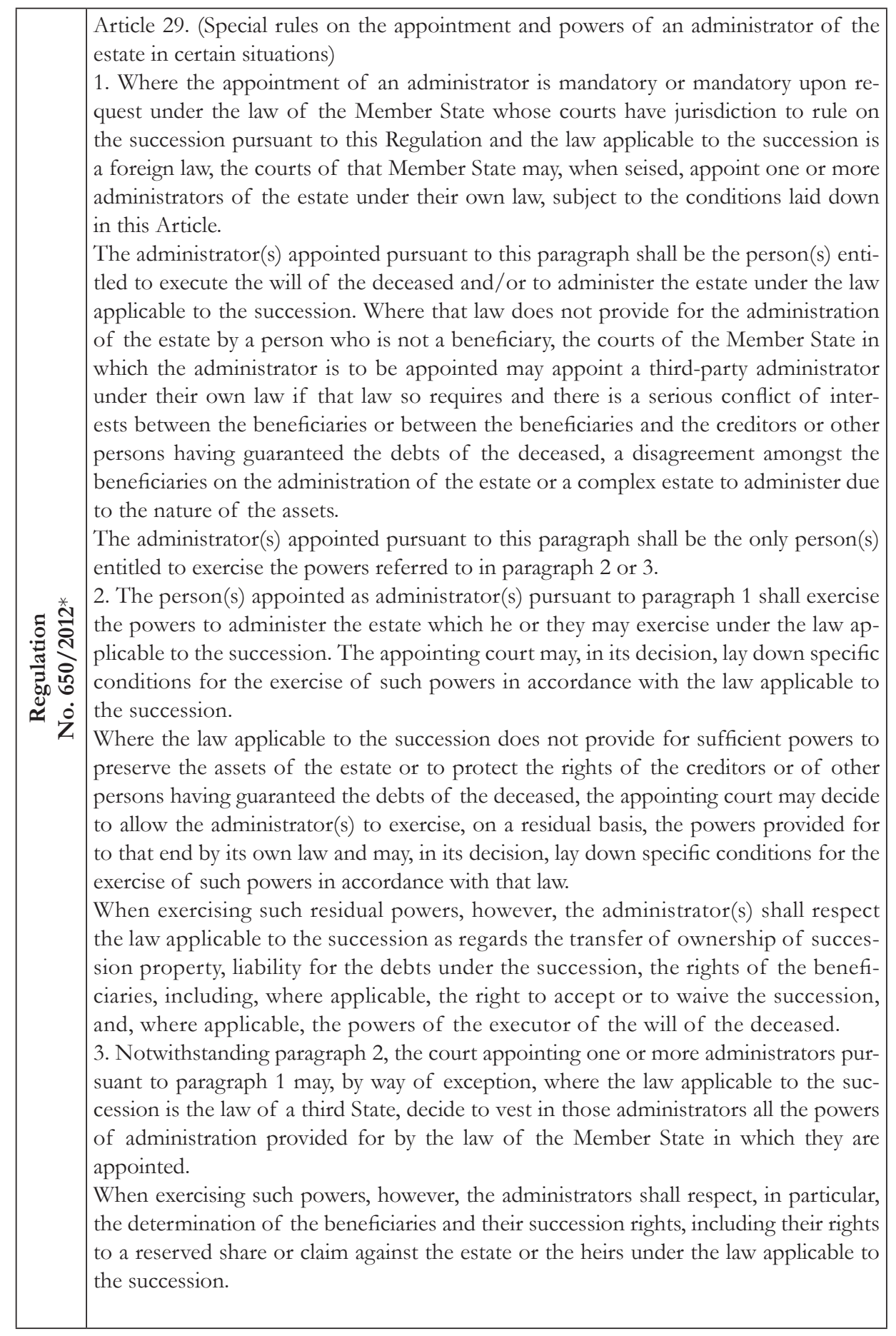




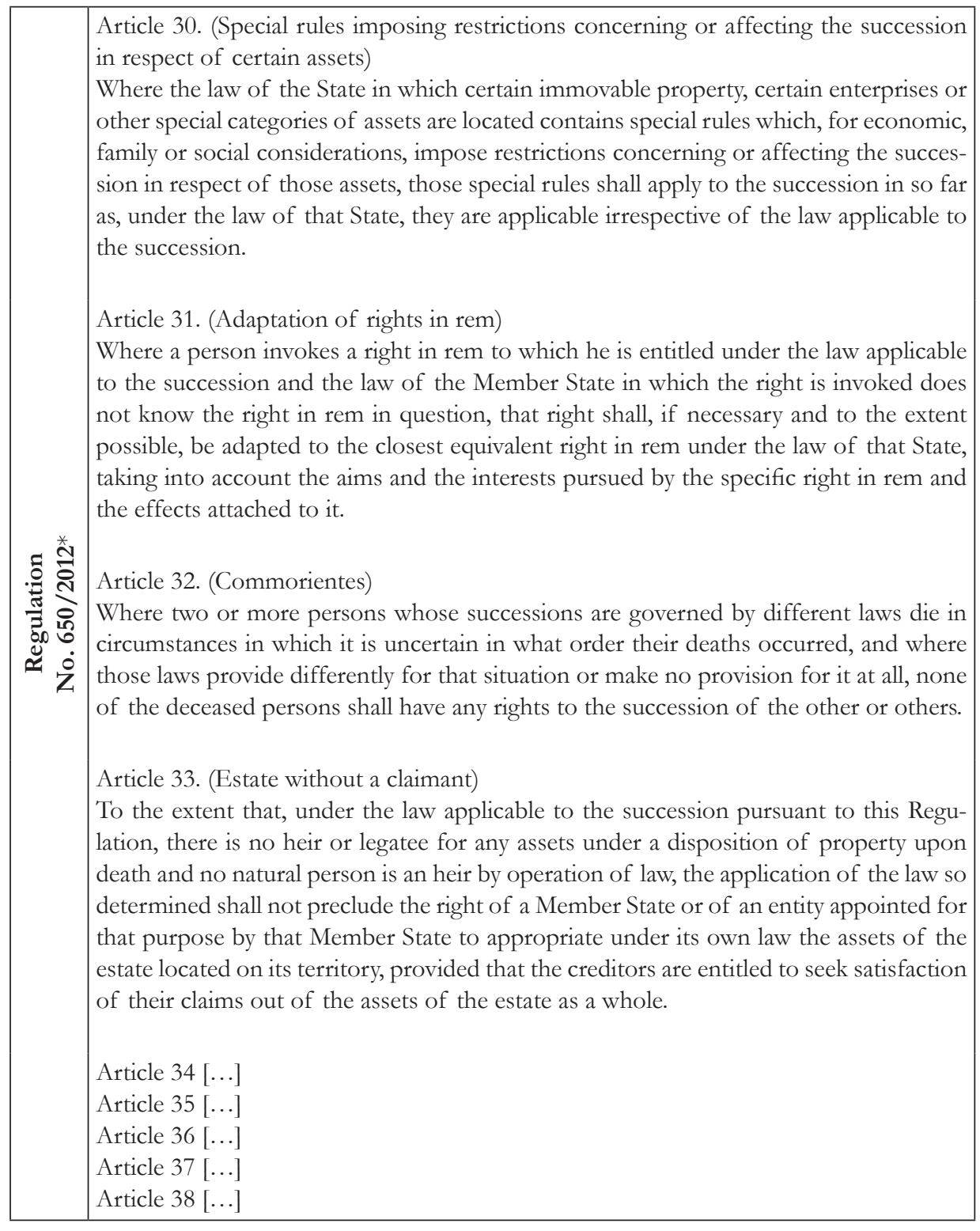

* Regulation (EU) No. 650/2012 of the European Parliament and of the Council of 4 July 2012. 


\section{Right in rem}

If we have a look at the rules on "right in rem," even more comparative developments of private international law can be observed in Japan and Poland (see: table 5). Chapter 9 of the 2011 Polish PIL Act ("Ownership and other property rights. Possession") provides a diversified choice-of-law rules from Article 41 to 45. On the other hand, Section 3 of the 2006 Japanese PIL Act ("Real Rights (Rights in rem), etc.") only provides Article 13, in which the traditional rule to apply the "law of the place where the subjected property of the right is situated" is adopted. These jurisdictions share the basic principle of attaching importance to the law where the property is situated, but it seems that they show slightly different solutions in a few cases as explained below.

Article 42 of the 2011 Polish PIL Act provides that property rights to the aircraft or to the ship, and to the rail vehicle shall be governed by the law of registration. In Japan, there was no written provisions on these issues, but it seems Japan would adopt similar solution. Speaking of the property rights to the ship, although there were a few judgements which applied the law of flag state to such issues, ${ }^{21}$ it has been pointed out that the law of registration shall apply. ${ }^{22}$ In case of the property rights to the aircraft, Japanese private international law also takes the position that the law of registration should be applied, rather than the law of its actual location. ${ }^{23}$

In Japan, there is also discussion on how the court should determine the law applicable to the property rights to the automobile. Traditionally, it has been insisted that the law of registration shall govern the property rights to the automobile as well. ${ }^{24}$ However, there was a Supreme Court's judgement that suggests, as an incidental remark, different theory. ${ }^{25}$ According to this judgement, as to the car which cannot be driven on public roadways, the law of its location shall apply; however, as to the car which can be driven on public roadways, the law of the place in which that car is mainly used shall apply. ${ }^{26}$ Among scholarly opinions, there is also another

21 See, for example, Yamaguchi District Court Judgement, June 26, 1967, 18(5-6) Lower Court Civil Cases [Kakyu-saibansho Minji Saibanrei-shu], p. 711; Akita District Court Judgement, January 23, 1971, 22(1-2) Lower Court Civil Cases [Kakyu-saibansho Minji Saibanrei-shu], p. 52.

22 See, for example, A. Takakuwa, "Article 10 of Horei and the Property Rights in Marine Affairs [Horei 10 Jo To Kaiji-bukeken]" [in:] Disputed Points of Private International Law [Kokusaishiho No Soten], eds. T. Sawaki, J. Akiba, new edition, Yuhikaku 1996, p. 110.

23 See, for example, Horei Research Group [Horei Kenkyu-kai], Issues on the Revision of Horei [Horei No Minaoshi Ni Kansuru Shomondai], vol. 2, Shojihomu 2003, p. 163.

24 See, for example, Y. Orimo, Private International Law: Itemized Discussion [Kokusaishibo: Kakuron], revised edition, Yuhikaku 1972, p. 92; Y. Tameike, Lecture on Private International Law [Kokusaishibo Kogi], $3^{\text {rd }}$ edition, Yuhikaku 2005, p. 343.

25 Supreme Court Judgement, October 29, 2002, 56(8) Supreme Court Civil Cases [Saiko-saibansho Minji Hanrei-shu], p. 1964.

26 Ibidem. 
theory insisting that in any case the property rights to the automobile shall be governed by the law of its actual location. ${ }^{27}$

Table 5. "Right in rem" under Japanese and Polish PIL Act

\begin{tabular}{|l|l|}
\hline & $\begin{array}{l}\text { Article 13. (1) A real right to movable or immovable and any other right requiring reg- } \\
\text { istration shall be governed by the law of the place where the subject property of the }\end{array}$ \\
right is situated. \\
(2) Notwithstanding the preceding paragraph, acquisition or loss of a right prescribed \\
in said paragraph shall be governed by the law of the place where the subject property \\
of the right is situated at the time when the facts constituting the cause of the acquisi- \\
tion or loss were completed.
\end{tabular}

27 Y. Nishitani, Challenges and Perspectives on the Governing Law of Right in Rem [Bukken-junkyoho Wo Meguru Kadai To Tenbo], "Journal on Civil and Commercial Law" [Minshobo Zasshi] 2007, vol. 136, no. 2, pp. 223 et seq. 


\section{Conclusion}

This summary of lecture underlines some characteristics of Japanese private international law in comparison with Polish private international law. Through the comparison, it is especially highlighted that considerable differences can be observed in the field of international succession and right in rem.

It should be noted that this lecture does not provide exhaustive enumeration of comparative points, and further detailed reviews would be desirable in the future. Specifically, another important contrast can be observed in the rules on intellectual property. Chapter 10 of 2011 Polish PIL Act provides provisions on intellectual property. This Chapter of 2011 Polish PIL Act consisting of two provisions is noteworthy considering that Japanese private international law still does not have any written choice-of-law provision on intellectual property.

\section{STRESZCZENIE}

\section{PRZEGLĄD PORÓWNAWCZY PRAWA PRYWATNEGO MIĘDZYNARODOWEGO W JAPONII}

Artykuł stanowi podsumowanie wykładu wygłoszonego podczas konferencji „O prawie japońskim”, zorganizowanej przez prof. Kamila Zeidlera na Wydziale Prawa i Administracji Uniwersytetu Gdańskiego w czerwcu 2019 r. Celem artykułu jest przedstawienie problematyki prawa prywatnego międzynarodowego w Japonii na tle prawno-porównawczym, ze szczególnym uwzględnieniem zagadnień dotyczących wyboru prawa właściwego. W pierwszej części omówiono tło historyczne rozwoju prawa prywatnego międzynarodowego w Japonii i Polsce, w dalszej części zaś przepisy dotyczące wyboru prawa właściwego w obu systemach prawnych. W konkluzji zwrócono uwage, że polska ustawa - Prawo prywatne międzynarodowe w rozdziale 10 zawiera przepisy szczegółowe dotyczące praw własności intelektualnej, podczas gdy w prawie japońskim nadal brakuje takich regulacji. 